\title{
VENDIDAITE, $\mathrm{Al}_{2}\left(\mathrm{SO}_{4}\right)(\mathrm{OH})_{3} \mathrm{Cl} \cdot 6 \mathrm{H}_{2} \mathrm{O}$, A NEW MINERAL FROM LA VENDIDA COPPER MINE, ANTOFAGASTA REGION, CHILE
}

\author{
NIKITA V. CHUKANOV \\ Institute of Problems of Chemical Physics, 142432 Chernogolovka, Moscow Oblast, Russia \\ SERGEY V. KRIVOVICHEV AND ANASTASIYA P. CHERNYATIEVA \\ Faculty of Geology, St Petersburg State University, Universitetskaya Nab. 7/9, St Petersburg, 199034 Russia
}

GERHARD MÖHN

Dr J. Wittemannstrasse 5, 65527 Niedernhausen, Germany

IGOR V. PEKOV

Faculty of Geology, Moscow State University, Leninskie Gory, 119991 Moscow, Russia

DMITRIY I. BELAKOVSKIY

Fersman Mineralogical Museum, Russian Academy of Sciences, Leninskiy Prospekt 18-2, Moscow, 119071 Russia

KONSTANTIN V. VAN

Institute of Experimental Mineralogy, Russian Academy of Sciences, Chernogolovka, Moscow Region 142432, Russia

JOACHIM A. LORENZ

Graslitzer Strasse 5, D-63791 Karlstein, Germany

\begin{abstract}
The new mineral vendidaite was discovered in the abandoned La Vendida mine, near Sierra Gorda, Antofagasta Region, Atacama desert, Chile. Associated minerals are aubertite, magnesioaubertite, belloite, eriochalcite, alunite, kaolinite, and halloysite. Vendidaite forms colorless platy crystals up to $0.01 \times 0.3 \times 0.3 \mathrm{~mm}$ in size; these occur in clusters up to $0.5 \mathrm{~mm}$ across. Vendidaite is brittle, with estimated Mohs' hardness of $2-2 \frac{1}{2}$ and perfect cleavage on $(010) . D_{\text {meas }}=1.97(1) \mathrm{g} / \mathrm{cm}^{3}, D_{\text {calc }}=1.974$ $\mathrm{g} / \mathrm{cm}^{3}$. The new mineral is optically biaxial (+), $\alpha=1.522(2), \beta=1.524(2), \gamma=1.527(2), 2 \mathrm{~V}$ (meas. $)=75(15)^{\circ}, 2 \mathrm{~V}$ (calc.) $=79^{\circ}$. Infra-red spectrum is given. The chemical composition (electron microprobe, $\mathrm{H}_{2} \mathrm{O}$ by gas chromatography) is (in wt. $\%$ ): $\mathrm{Al}_{2} \mathrm{O}_{3}$ 28.51, $\mathrm{Fe}_{2} \mathrm{O}_{3} 1.39, \mathrm{SO}_{3} 22.38, \mathrm{Cl} 9.87, \mathrm{H}_{2} \mathrm{O} 38.8, \mathrm{O}=\mathrm{Cl}-2.23$, total 98.72. The empirical formula is: $\mathrm{Al}_{1.96} \mathrm{Fe}^{3+}{ }_{0.06}\left(\mathrm{SO}_{4}\right)_{0.98}$ $\mathrm{Cl}_{0.98}(\mathrm{OH})_{3.12} \cdot 5.98 \mathrm{H}_{2} \mathrm{O}$. The crystal structure was solved using single-crystal X-ray diffraction data $(R 1=0.044)$. Vendidaite is monoclinic, space group $C 2 / c, a 11.9246(16), b 16.134(2), c 7.4573(9) \AA, \beta 125.815(2)^{\circ}, V 1163.4(3) \AA^{3}$, and $Z=4$. The structure is based upon $\left[\mathrm{Al}_{2}(\mathrm{OH})_{3}\left(\mathrm{H}_{2} \mathrm{O}\right)_{6}\right]^{3+}$ chains of edge- and corner-sharing $\left[\mathrm{Al}\left(\mathrm{OH}, \mathrm{H}_{2} \mathrm{O}\right)\right]$ octahedra running parallel to the $a$ axis. The chains are linked by hydrogen bonds to $\left(\mathrm{SO}_{4}\right)$ tetrahedra and $\mathrm{Cl}^{-}$anions to form pseudolayers parallel to the (010) plane.

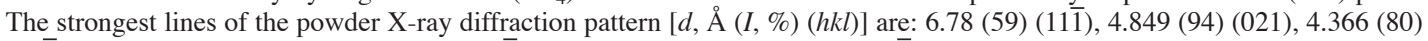
$(13 \overline{1}), 4.030$ (75) $(040,111), 3.855$ (100) (31̄) , 3.285 (59) (131), $2.435(52)(26 \overline{1})$. Type material is deposited in the collections of the Fersman Mineralogical Museum of the Russian Academy of Sciences, Moscow, Russia, registration number 4335/1.
\end{abstract}

Keywords: vendidaite, La Vendida mine, Chile, new mineral, aluminum chloride hydroxide sulfate, crystal structure.

§Corresponding author: chukanov@icp.ac.ru 


\section{INTRODUCTION}

The abandoned open pit of the La Vendida copper mine (Mina La Vendida, until 1990 known as Rio Tinto mine) is situated about $3 \mathrm{~km} \mathrm{WNW}$ of the Sierra Gorda village, Antofagasta Region, Atacama desert, Chile. The copper sulfide mineralization is associated with daciticandesitic volcanic breccias. The supergene mineralization is represented mainly by sulfates, chlorides, and clay minerals. La Vendida mine is the type locality for the copper hydroxychloride minerals belloite $\mathrm{Cu}(\mathrm{OH}) \mathrm{Cl}$ (Schlüter et al. 2000) and anatacamite $\mathrm{Cu}_{2}(\mathrm{OH})_{3} \mathrm{Cl}$ (Malcherek \& Schlüter 2010).

The present paper describes a new mineral species from the La Vendida mine, vendidaite. The mineral and its name have been approved by the IMA Commission on New Minerals, Nomenclature and Classification (IMA no. 2012-089). Vendidaite is a representative of a new structure type. Among 12 natural hydrous aluminum sulfates without additional cations, vendidaite is the only mineral containing $\mathrm{Cl}$ as a speciesdefining component.

The type material is deposited in the collection of the Fersman Mineralogical Museum of the Russian Academy of Sciences, Moscow, Russia, registration number 4335/1.

\section{GENERAL APPEARANCE AND PHYSICAL PROPERTIES}

Specimens with vendidaite were collected in the La Vendida open pit by one of the authors (GM) in January 2011. The holotype material originates from a $2 \times 1$

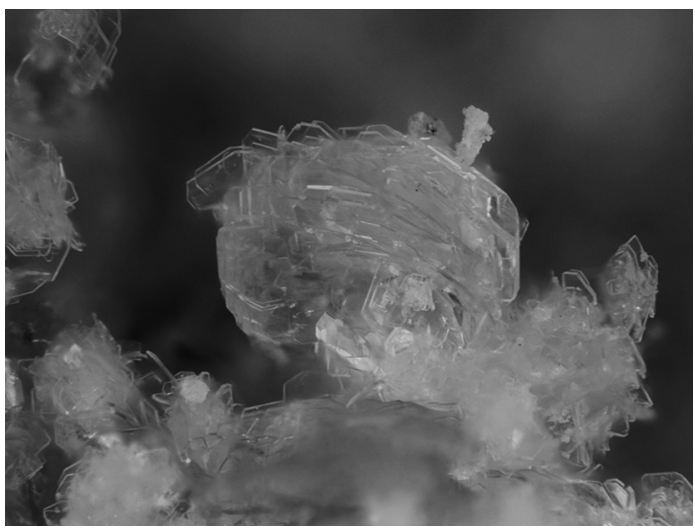

FIG. 1. Aggregates of crystals of vendidaite. The crystal forms are: $\{010\}$ major, $\{100\}$ and $\{001\}$ subordinate. FOV: $1 \mathrm{~mm}$ (a) and $0.3 \mathrm{~mm}$ (b). Photographer: $\mathrm{M}$. Burkhardt. $\times 1 \mathrm{~m}^{3}$ block at the edge of the quarry. Subsequently vendidaite was found on the dumps of the La Vendida mine. Associated minerals are intermediate members of the aubertite-magnesioaubertite solid-solution series, belloite, eriochalcite, alunite, kaolinite, and halloysite. Belloite (formed as a product of alteration of eriochalcite) and vendidaite are the latest minerals in this association.

Sulfate minerals (mainly alunite and jarosite) are abundant in the quarry. Associations of copper sulfates and chlorides (like that bearing vendidaite) are located in small areas from 1 to $5 \mathrm{~m}$ across where secondary minerals occur in thin fissures. The host rocks (daciticandesitic volcanic breccias) are strongly altered.

Vendidaite forms colorless transparent (with vitreous luster) platy crystals up to $0.01 \times 0.3 \times 0.3 \mathrm{~mm}$ in size, flattened on (010), and forming clusters up to 0.5 $\mathrm{mm}$ across (Fig. 1a,b), as well as white, fine-grained aggregates. The major form of the vendidaite crystals is $\{010\}$; the subordinate forms are $\{100\},\{001\}$, and $\{101\}$. Vendidaite is brittle, with Mohs' hardness of $2-2 \frac{1}{2}$ (estimated using cleavage planes of gypsum and calcite) and perfect cleavage on (010). The density measured by flotation in heavy liquids is equal to $1.97(1) \mathrm{g} / \mathrm{cm}^{3}$, which agrees well with the value of 1.974 $\mathrm{g} / \mathrm{cm}^{3}$ calculated from the empirical formula.

Vendidaite is optically biaxial ( + ), $\alpha=1.522(2), \beta$ $=1.524(2), \gamma=1.527(2), 2 V_{\text {calc }}=79^{\circ}$. Due to the lack of material, the refractive indexes and other optical properties were measured from one mount in immersion liquids with no possibility to rotate the grains. Thus $2 V_{\text {meas }}$ could only be very roughly estimated as

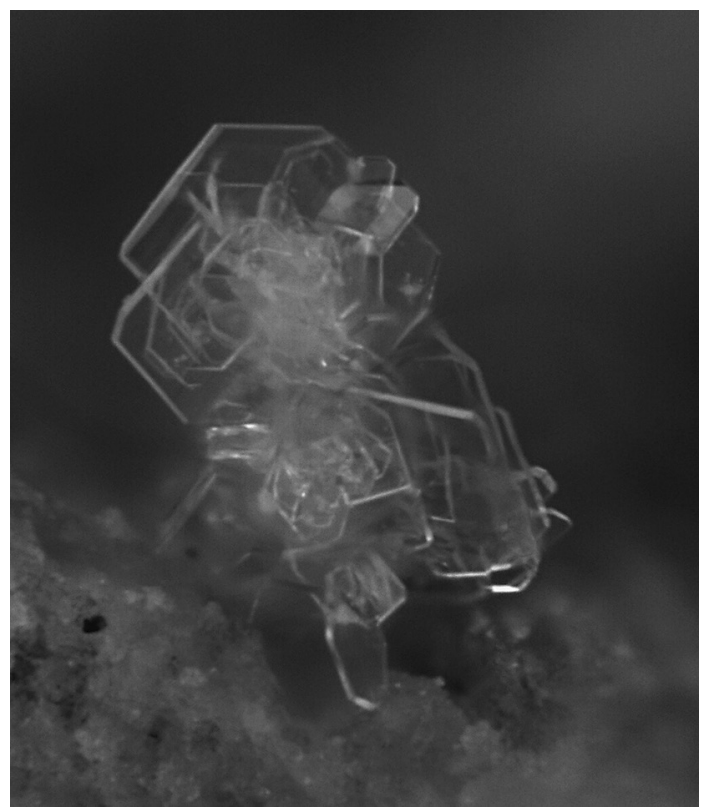


large (between $60^{\circ}$ and $90^{\circ}$ ) by the conoscopic interference pattern on the section perpendicular to the $2 \mathrm{~V}$ bisector. Grains with orientation more suitable for the $2 \mathrm{~V}$ measurement were not found because of the perfect cleavage. No dispersion of optical axes was observed. The orientation is $Z=b ; X$ and $Y$ lie in the $a c$ plane.

In order to obtain an infrared (IR) absorption spectrum, vendidaite powder was mixed with anhydrous $\mathrm{KBr}$, pelletized, and analyzed using an ALPHA FTIR spectrometer (Bruker Optics) at a resolution of 4 $\mathrm{cm}^{-1}$ and using 16 scans. IR spectrum of an analogous pellet of pure $\mathrm{KBr}$ was used as a reference. Absorption bands in the IR spectrum of vendidaite (Fig. 2) and their assignments are $\left(\mathrm{cm}^{-1} ; \mathrm{s}-\right.$ strong band, w - weak band, sh - shoulder): 3640sh, 3585, 3490sh, 3421, 3293s, $3190 \mathrm{sh}, 3164 \mathrm{~s}, 2989$ (O-H stretching vibrations of $\mathrm{OH}^{-}$anions and $\mathrm{H}_{2} \mathrm{O}$ molecules), 2521w, 2445w, 2299w (combination modes and/or $\mathrm{O}-\mathrm{H}$ stretching vibrations of acid $\mathrm{OH}$ groups), 1685sh, 1646 (bending vibrations of $\mathrm{H}_{2} \mathrm{O}$ molecules), 1168, 1107s, 1040 (asymmetric stretching vibrations of $\mathrm{SO}_{4}{ }^{2-}$ anions), 993w (symmetric $\mathrm{S}-\mathrm{O}$ stretching vibrations of $\mathrm{SO}_{4}{ }^{2-}$ anions), $882 \mathrm{w}, 843$, $760 \mathrm{sh}, 700$ (Al $\cdots \mathrm{O}-\mathrm{H}$ bending vibrations), 639, 620, 609 (O-S-O bending vibrations of $\mathrm{SO}_{4}{ }^{2-}$ anions), 547, 497 (Al-O stretching vibrations, possibly combined with librational vibrations of $\mathrm{H}_{2} \mathrm{O}$ molecules), 460, 379 (mixed lattice vibrations). A relatively low intensity of the symmetric $\mathrm{S}-\mathrm{O}$ stretching vibrations of the $\mathrm{SO}_{4}{ }^{2-}$ anions [at $993 \mathrm{~cm}^{-1}$, non-degenerate $v_{1}\left(\mathrm{~A}_{1}\right)$ mode] and a weak splitting of the asymmetric stretching vibrations of $\mathrm{SO}_{4}{ }^{2-}$ anions [in the range $1040-1170 \mathrm{~cm}^{-1}$, degenerate
$v_{3}\left(F_{2}\right)$ mode] reflect a relatively weak distortion of the $\mathrm{SO}_{4}$ tetrahedra.

Bands of B-, C-, and N-bearing groups are absent in the IR spectrum of vendidaite. Weak IR bands at 2299 , 2445 , and $2521 \mathrm{~cm}^{-1}$ indicate the presence of trace amounts of $\mathrm{HSO}_{4}{ }^{-}$ions that could have formed as a result of reversible proton transfer from a water molecule in accordance with the following dynamic equilibrium: $\mathrm{H}_{2} \mathrm{O}+\mathrm{SO}_{4}{ }^{2-} \leftrightarrow \mathrm{OH}^{-}+\mathrm{HSO}_{4}^{-}$. This phenomenon is very typical for nominally neutral sulfates, phosphates and arsenates (see, e.g., Chukanov et al. 2010, 2012; Nestola et al. 2012).

The IR spectrum of vendidaite is unique and can be used as a reliable diagnostic tool.

\section{Chemical DATA}

Five electron-microprobe analyses were carried out using a VEGA TS 5130MM SEM equipped with an EDX analyzer [INCA $\mathrm{Si}(\mathrm{Li})$ detector], at an operating voltage of $20 \mathrm{kV}$ and a beam current of $0.6 \mathrm{nA}$. The program INCA Energy 200 was used for the analytical data calculation. Attempts to use the WDS mode with higher beam currents were unsuccessful because of the instability of the mineral containing significant amounts of volatile components. $\mathrm{H}_{2} \mathrm{O}$ was determined by gas chromatography of products of ignition at 1200 ${ }^{\circ} \mathrm{C}$ with a Vario MICRO cube analyzer (Elementar $\mathrm{GmBH}$, Germany). $\mathrm{CO}_{2}, \mathrm{~N}_{2} \mathrm{O}_{5}$, and $\mathrm{B}_{2} \mathrm{O}_{3}$ were not analyzed because of the absence of absorption bands corresponding to vibrations of $\mathrm{C}-\mathrm{O}, \mathrm{N}-\mathrm{O}$, and $\mathrm{B}-\mathrm{O}$

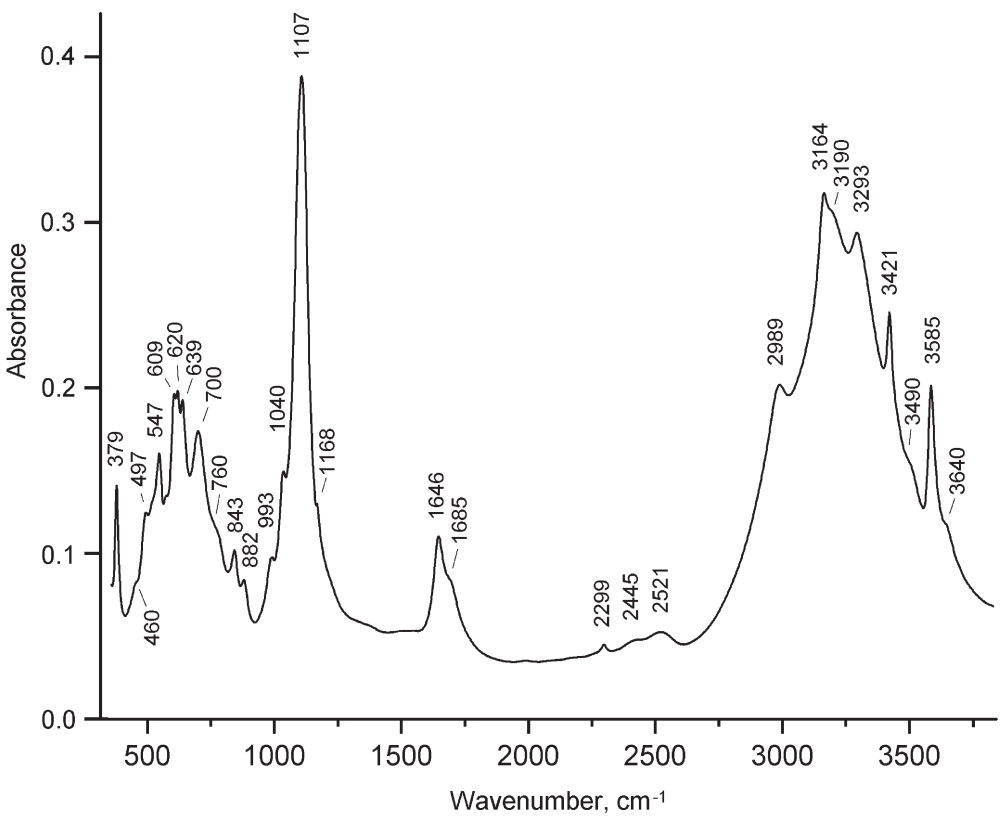

FIG. 2. The IR spectrum of vendidaite. 
bonds in the IR spectrum. The analytical data are given in Table 1. Contents of F, Na, Mg, Si, P, K, Ca, Mn, Cu, $\mathrm{Zn}, \mathrm{As}, \mathrm{Br}, \mathrm{Sr}, \mathrm{Pb}$ are below detection limits.

The empirical formula (based on 14 atoms $\mathrm{O}+\mathrm{Cl}$ pfu and $\mathrm{OH} / \mathrm{H}_{2} \mathrm{O}$ ratio calculated for charge balance) is $\mathrm{Al}_{1.96} \mathrm{Fe}^{3+}{ }_{0.06}\left(\mathrm{SO}_{4}\right)_{0.98} \mathrm{Cl}_{0.98}(\mathrm{OH})_{3.12} \cdot 5.98 \mathrm{H}_{2} \mathrm{O}$. The simplified formula is $\mathrm{Al}_{2}\left(\mathrm{SO}_{4}\right)(\mathrm{OH})_{3} \mathrm{Cl} \cdot 6 \mathrm{H}_{2} \mathrm{O}$, which requires $\mathrm{Al}_{2} \mathrm{O}_{3}$ 29.59, $\mathrm{SO}_{3} 23.23, \mathrm{Cl} 10.29, \mathrm{H}_{2} \mathrm{O} 39.21$, $\mathrm{O}=\mathrm{Cl}-2.32$, total 100.00 wt. $\%$.

The Gladstone-Dale compatibility index is: $1-\left(\mathrm{K}_{\mathrm{p}} /\right.$ $\left.\mathrm{K}_{\mathrm{c}}\right)=0.035$ ("excellent").

Vendidaite is insoluble in water and dissolves slowly in warm $20 \%$ hydrochloric acid. The aqueous extract from vendidaite-bearing aggregates has a $\mathrm{pH}$ value of about 4 , which indicates that this mineral is stable in a weak-acid environment.

\section{X-RAY DIFFRACTION DATA AND CRYSTAL STRUCTURE}

Powder X-ray diffraction data (Table 2) were measured with a Stoe IPDS II image plate diffractometer using the Gandolfi method (MoK $\alpha$ radiation; the distance between sample and detector was $200 \mathrm{~mm}$ ). The obtained diffraction pattern was indexed in the monoclinic (space group $\mathrm{C} 2 / \mathrm{c}$ ) unit cell, in agreement with the single-crystal diffraction data. Unit-cell parameters refined from the powder data are: $a$ 11.91(4), $b$ 16.13(2), c 7.46(3) $\AA, \beta 125.8(2)^{\circ}, V$ 1164(7) $\AA^{3}$.

A crystal of vendidaite was mounted on a Bruker Kappa APEX DUO diffractometer with a crystal-todetector distance of $4 \mathrm{~cm}$. A hemisphere of three-dimensional data was collected using $\mathrm{MoK} \alpha \mathrm{X}$-radiation and frame widths of $0.5^{\circ}$ in $\omega$, with $60 \mathrm{~s}$ used to acquire each frame. The unit-cell dimensions were refined on the basis of 9817 reflections (Table 3). The systematic absences of reflections are consistent with the spacegroup $C 2 / c$. The data were reduced using the Bruker program SAINT. A semi-empirical absorption-correction based upon the intensities of equivalent reflections was applied, and the data were corrected for Lorentz, polarization, and background effects.

The Bruker SHELXTL system of programs was used for the refinement of the crystal structure on the basis of $F^{2}$. The structure was solved by direct methods. Refinement of all atom-position parameters, allowing for the anisotropic displacement of all atoms except $\mathrm{H}$, and the inclusion of a refinable weighting-scheme of the structure factors, resulted in a final agreement index $(R 1)$ of 0.044 , calculated for the 2034 unique observed reflections $(|F \mathrm{O}|>4 \sigma F)$, and a goodness-of-fit $(S)$ of 1.024. The final atom parameters are listed in Table 4, and selected interatomic distances and the geometrical parameters of the hydrogen bonding scheme are given in Table 5. Observed and calculated structure-factors can be acquired from the Depository of Unpublished Data on the MAC website [document Vendidaite CM51_559].

The structure of vendidaite contains one symmetrically independent $\mathrm{Al}$ site octahedrally coordinated by three $\mathrm{OH}$ groups and three $\mathrm{H}_{2} \mathrm{O}$ molecules (Fig. 3a). Two adjacent $\left[\mathrm{Al}(\mathrm{OH})_{3}\left(\mathrm{H}_{2} \mathrm{O}\right)_{3}\right]$ octahedra share the $\mathrm{O}_{\mathrm{h}} 1 \cdots \mathrm{O}_{\mathrm{h}} 1$ edge to form a $\left[\mathrm{Al}_{2}(\mathrm{OH})_{4}\left(\mathrm{H}_{2} \mathrm{O}\right)_{6}\right]$ dimer with the $\mathrm{O}_{\mathrm{h}} 1-\mathrm{Al}-\mathrm{O}_{\mathrm{h}} 1$ bond angle equal to $76.96(6)^{\circ}$, i.e., considerably more acute than the ideal angle of $90^{\circ}$. The dimers are further linked by sharing the $\mathrm{O}_{\mathrm{h}} 4$ atoms to form $\left[\mathrm{Al}_{2}(\mathrm{OH})_{3}\left(\mathrm{H}_{2} \mathrm{O}\right)_{6}\right]^{3+}$ chains running parallel to the $a$ axis.

The crystal structure contains $\left(\mathrm{SO}_{4}\right)^{2-}$ groups and $\mathrm{Cl}^{-}$anions held in the structure by hydrogen bonds alone (Fig. 3b, c). The average $<\mathrm{S}-\mathrm{O}\rangle$ bond length in the sulfate group is $1.478 \AA$, which is in a good agreement with the grand average distance of $1.473 \AA$ given for sulfate minerals by Hawthorne et al. (2000). The sulfate group is located on the twofold symmetry axis and consists of two $\mathrm{O} 5$ and two $\mathrm{O} 7$ atoms. The $\mathrm{O} 5$ atom accepts three $\mathrm{H}$ bonds from the $\mathrm{OH}(1), \mathrm{H}_{2} \mathrm{O}(3)$, and $\mathrm{H}_{2} \mathrm{O}(6)$ groups, whereas the $\mathrm{O} 7$ atom accepts two bonds from two symmetrically equivalent $\mathrm{H}_{2} \mathrm{O}(2)$ molecules (Fig. 3b). The $\mathrm{Cl}$ atom is also on the two-fold axis and accepts six $\mathrm{H}$ bonds from two $\mathrm{H}_{2} \mathrm{O}(2)$, two $\mathrm{H}_{2} \mathrm{O}(3)$, and two $\mathrm{H}_{2} \mathrm{O}(6)$ groups (Fig. 3c). In total, each $\mathrm{H}_{2} \mathrm{O}$ molecule is linked to the $\mathrm{Al}$ atom and donates two $\mathrm{H}$ bonds to $\mathrm{O}$ and/or $\mathrm{Cl}$ atoms. Each $\mathrm{OH}$ group is linked to two $\mathrm{Al}^{3+}$ cations and donates one $\mathrm{H}$ bond to either an $\mathrm{O}$ or $\mathrm{Cl}$ atom.

TABLE 1. CHEMICAL COMPOSITION OF VENDIDAITE BASED ON FIVE ELECTRONMICROPROBE ANALYSES

\begin{tabular}{lcccl}
\hline Constituent & Mean content, wt.\% & Range & Standard deviation & Probe Standard \\
\hline $\mathrm{Al}_{2} \mathrm{O}_{3}$ & 28.51 & $27.71-29.24$ & 0.4 & albite \\
$\mathrm{Fe}_{2} \mathrm{O}_{3}$ & 1.39 & $1.21-1.68$ & 0.15 & $\mathrm{Fe}$ \\
$\mathrm{SO}_{3}$ & 22.38 & $21.86-22.73$ & 0.3 & $\mathrm{BaSO}_{4}$ \\
$\mathrm{Cl}$ & 9.87 & $9.67-10.17$ & 0.15 & $\mathrm{NaCl}$ \\
$\mathrm{H}_{2} \mathrm{O}$ & $38.8(2)^{*}$ & & & \\
$\mathrm{O}=\mathrm{Cl}$ & -2.23 & & & \\
Total & 98.72 & & & \\
\hline
\end{tabular}

Note: *Determined by gas chromatography 
TABLE 2. POWDER X-RAY DIFFRACTION DATA FOR VENDIDAITE

\begin{tabular}{|c|c|c|c|c|}
\hline$I_{\mathrm{obs}}$ & $d_{\text {obs }}, \AA$ & $I_{\text {calc }^{*}}{ }^{*}$ & $d_{\text {calc }}, \AA^{* *}$ & $h k l$ \\
\hline 13 & 8.12 & 10 & 8.067 & 020 \\
\hline 59 & 6.78 & 53 & 6.762 & $11 \overline{1}$ \\
\hline 94 & 4.849 & 74 & 4.839 & 021 \\
\hline 80 & 4.366 & 68 & 4.360 & $13 \overline{1}$ \\
\hline 75 & 4.030 & 39,29 & $4.034,4.020$ & $04 \underline{0}, 111$ \\
\hline 100 & 3.855 & 100 & 3.852 & $31 \overline{1}$ \\
\hline 43 & 3.745 & 41 & 3.724 & $20 \overline{2}$ \\
\hline 3 & 3.480 & 2 & 3.453 & $11 \overline{2}$ \\
\hline 59 & 3.285 & 63 & 3.286 & 131 \\
\hline 12 & 3.187 & 12 & 3.192 & $33 \overline{1}$ \\
\hline 34 & 2.973 & 12 & 2.961 & $15 \overline{1}$ \\
\hline 22 & 2.871 & 17 & 2.882 & $40 \overline{2}$ \\
\hline 32 & 2.831 & 28 & 2.831 & 022 \\
\hline 45 & 2.764 & 45 & 2.765 & 330 \\
\hline 5 & 2.544 & 5 & 2.547 & 151 \\
\hline 52 & 2.435 & 44 & 2.437 & $26 \overline{1}$ \\
\hline 23 & 2.333 & 11,10 & $2.330,2.316$ & $22 \overline{3}, 420$ \\
\hline 32 & 2.254 & 28 & 2.254 & $33 \overline{3}$ \\
\hline 4 & 2.182 & 2,4 & $2.180,2.176$ & $26 \overline{2}, 53 \overline{2}$ \\
\hline 14 & 2.072 & 17 & 2.074 & 440 \\
\hline 13 & 2.007 & $1,8,4$ & $2.010,2.009,2.006$ & $222,062,261$ \\
\hline 17 & 1.965 & 11,8 & $1.968,1.966$ & $35 \overline{3}, 46 \overline{2}$ \\
\hline 12 & 1.908 & 4,4 & $1.911,1.904$ & $37 \overline{2}, 28 \overline{1}$ \\
\hline 8 & 1.854 & 6,8 & $1.862,1.848$ & $40 \overline{4}, 15-3$ \\
\hline 7 & 1.800 & $1,9,2$ & $1.803,1.803,1.798$ & $04 \underline{3}, 62 \overline{1}, 460$ \\
\hline 8 & 1.764 & $5,4,1$ & $1.767,1.766,1.763$ & $20 \overline{4}, 113,190$ \\
\hline 11 & 1.746 & 10,4 & $1.746,1.742$ & $33 \overline{4}, 312$ \\
\hline 15 & 1.680 & $2,14,5$ & $1.682,1.681,1.676$ & $71 \overline{3}, 64 \overline{1}, 281$ \\
\hline 7 & 1.653 & $2,7,1$ & $1.657,1.656,1.652$ & $48 \overline{1}, 57 \underline{2}, 48 \overline{2}$ \\
\hline 6 & 1.602 & 2,6 & $1.602,1.599$ & $35 \overline{4}, 19 \overline{2}$ \\
\hline 2 & 1.562 & 4,1 & $1.563,1.559$ & $66 \overline{3}, 0.10 .1$ \\
\hline 4 & 1.495 & $2,2,1$ & $1.498,1.498,1.492$ & $73 \overline{1}, 75-3,75 \overline{2}$ \\
\hline 6 & 1.444 & 8 & 1.443 & $66-4$ \\
\hline 7 & 1.422 & 8,2 & $1.422,1.422$ & $2.10 .1,391$ \\
\hline 2 & 1.311 & 1,2 & $1.315,1.310$ & 590,571 \\
\hline 2 & 1.285 & 2 & 1.284 & $66 \overline{5}$ \\
\hline 4 & 1.253 & 5,4 & $1.253,1.250$ & 392,204 \\
\hline 2 & 1.186 & 1,1 & $1.186,1.186$ & $64 \overline{6}, 373$ \\
\hline 1 & 1.103 & 2,2 & $1.103,1.103$ & 065,860 \\
\hline
\end{tabular}

${ }^{*}$ For the calculated $X$-ray powder pattern only reflections with $I_{\text {calc }} \geq 1$ are given.

${ }^{* *}$ Calculated for unit cell parameters obtained from single-crystal data.

Together with the $\left[\mathrm{Al}_{2}(\mathrm{OH})_{3}\left(\mathrm{H}_{2} \mathrm{O}\right)_{6}\right]^{3+}$ chains, the $\mathrm{Cl}^{-}$anions and $\left(\mathrm{SO}_{4}\right)^{2-}$ groups form pseudo-layers parallel to (010) (Fig. 4). The pseudo-layers are characterized by the high density of hydrogen bonds: eight out of ten $\mathrm{H}$ bonds formed by each $\mathrm{SO}_{4}$ tetrahedron and four out of six bonds formed by each $\mathrm{Cl}$ atom belong to the layer. The presence of pseudo-layers in the structure of vendidaite may explain the platy morphology of its crystals and their perfect cleavage.

\section{DisCUSSION}

No minerals related to vendidaite in terms of its crystal structure or powder X-ray diffraction pattern,
IR spectrum, and optical data are known. Vendidaite is the first natural chloride sulfate with $\mathrm{Al}$ as the only species-defining metal cation, although synthetic polyaluminium chloride hydroxide sulfate materials (PACS) are well-known for their use as a coagulant, and sometimes as a precipitant for treatment of water intended for human consumption (European Standard EN 883, 2005). Unfortunately, information about the details of synthesis and crystal structures of aluminium chloride sulfates is patented.

Hypothetically, the source of aluminum for vendidaite formation and associated clay minerals was feldspar alteration. Indeed, grains of feldspar in the host rocks are strongly altered, which could be partly the result of 


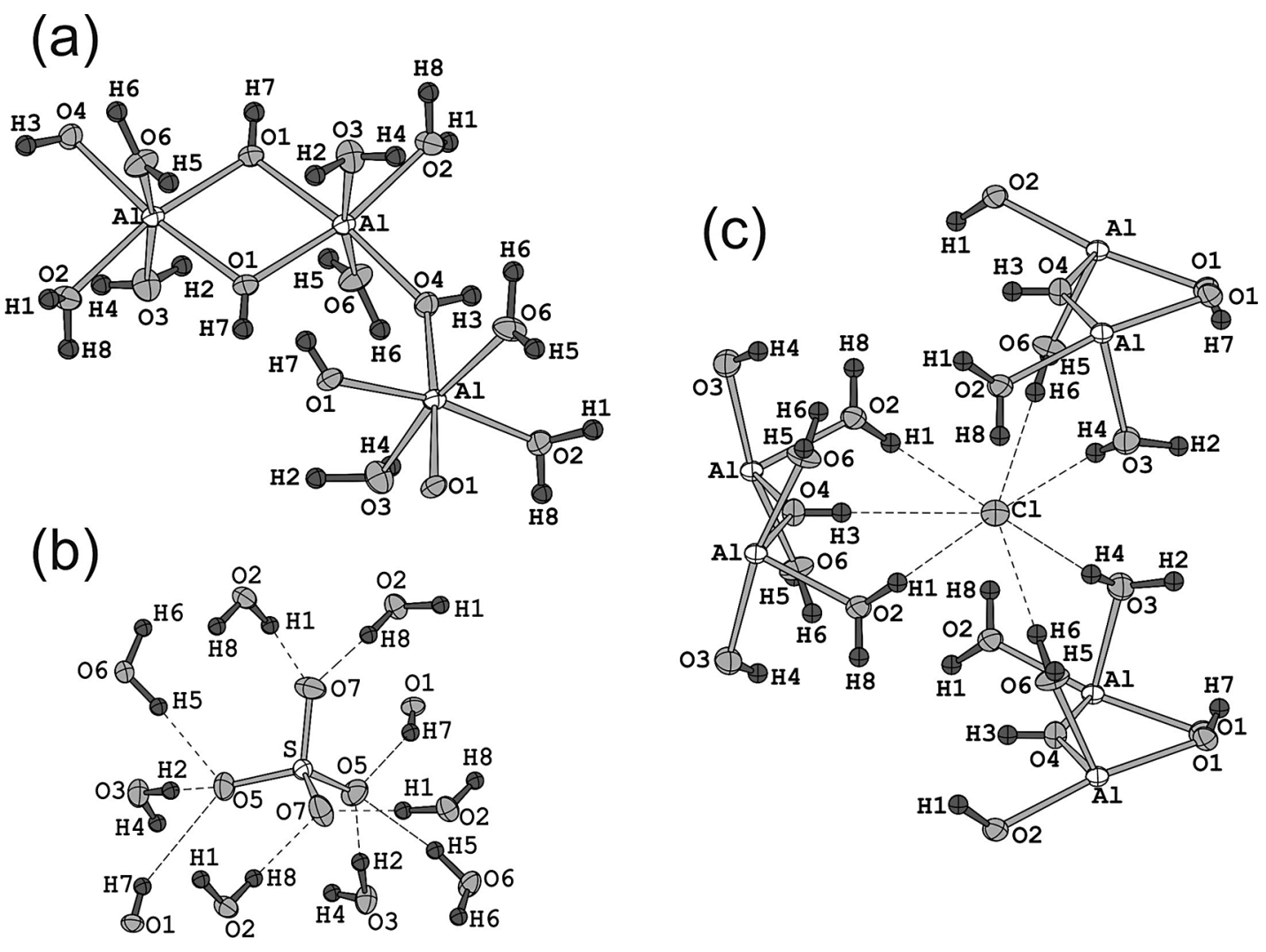

FIG. 3. Constituents of the crystal structure of vendidaite: linkage mode of the $\left[\mathrm{Al}(\mathrm{OH})_{3}\left(\mathrm{H}_{2} \mathrm{O}\right)_{3}\right]$ octahedra (a), and coordination environment of the $\mathrm{SO}_{4}$ groups (b) and $\mathrm{Cl}^{-}$anions (c). Ellipsoids are drawn at $50 \%$ probability level; $\mathrm{H}^{\cdots} \mathbf{A}$ bonds are shown as dashed lines ( $\mathbf{A}=$ acceptor; cf. Table 5).

its exposure to sulfuric acid formed during the oxidation of primary sulfides. The source of the chlorine is unclear. Most probably, formation of secondary Cl-bearing minerals in oxidation zones of ore deposits in the Atacama Desert of northern Chile is an ongoing process that has occurred intermittently since the onset of hyperaridity and is related to saline ground waters (see Reich et al. 2008).

Strongly altered magmatic rocks containing aggregates of secondary sulfates (kröhnkite, tamarugite, jarosite, aubertite, botryogen, etc.), as well as clay minerals, are exposed in different parts of the quarry, but the vendidaite-bearing mineral association has only been found in a small area. One can suppose that the formation of vendidaite is possible in narrow ranges of $\mathrm{pH}$ and/or activities of species-forming cations and anions. Another possible cause of the uniqueness of vendidaite is the strongly pronounced tendency of the system $\mathrm{Al}_{2}\left(\mathrm{SO}_{4}\right)_{3}-\mathrm{AlCl}_{3}-\mathrm{H}_{2} \mathrm{O}$ to form glasses with stoichiometry $\mathrm{Al}\left(\mathrm{SO}_{4}\right) \mathrm{Cl} \cdot n \mathrm{H}_{2} \mathrm{O}$ (Kirilenko 2010). Hypothetically, the formation of crystalline aluminium chlo- ride sulfates (known mainly as basic salts) is promoted by a high activity of $\mathrm{OH}$ groups, i.e., by relatively high $\mathrm{pH}$ values of mineral-forming solutions.

The eight hydrogen bonds determined from structural data for vendidaite correspond well to the eight bands of the $\mathrm{O}-\mathrm{H}$ stretching vibrations observed in the IR spectrum in the range $2900-3700 \mathrm{~cm}^{-1}$. The following empirical correlation between $\mathrm{O}-\mathrm{H}$ stretching frequencies $v$ in IR spectra of minerals $\left(\right.$ in $\mathrm{cm}^{-1}$ ) and $\mathrm{O} \cdots \mathrm{O}$ distances $\mathrm{d}(\mathrm{O} \cdots \mathrm{O})$ determined from structural data (in $\AA$ ) were established by Libowitzky (1999): v $=3592-304 \cdot 10^{9} \cdot \exp [-\mathrm{d}(\mathrm{O} \cdots \mathrm{O}) / 0.1321]$. As was noted earlier by Chukanov et al. (2011), at high frequencies

FIG. 4. Crystal structure of vendidaite projected along $c$ (a) and $b(\mathrm{~b})$ axes. Legend: $\left[\mathrm{Al}(\mathrm{OH})_{3}\left(\mathrm{H}_{2} \mathrm{O}\right)_{3}\right]$ octahedra are dark grey, $\mathrm{SO}_{4}$ tetrahedra are cross-hatched; $\mathrm{H} \cdots \mathbf{A}$ bonds are shown as light grey lines. 

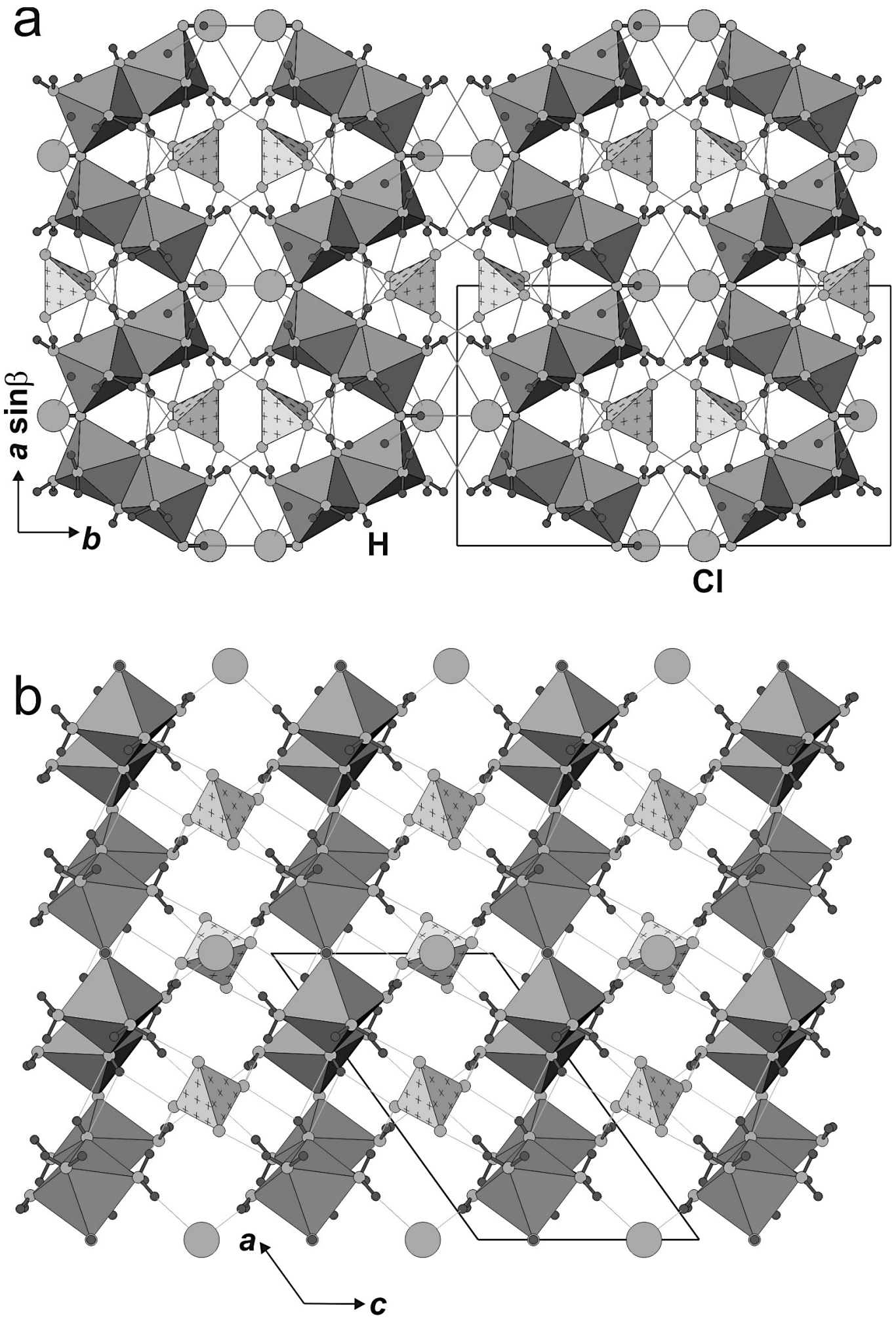
TABLE 3. CRYSTALLOGRAPHIC DATAAND REFINEMENT PARAMETERS FOR VENDIDAITE

\begin{tabular}{|c|c|}
\hline \multicolumn{2}{|l|}{ Crystal data } \\
\hline Temperature & $296 \mathrm{~K}$ \\
\hline Radiation, wavelength & $\mathrm{MoK}_{\alpha}, 0.71073 \AA$ \\
\hline Crystal system & monoclinic \\
\hline Space group & $C 2 / c$ \\
\hline $\begin{array}{l}\text { Unit-cell dimensions } a, b, c \\
(\AA), \beta\left(^{\circ}\right)\end{array}$ & $\begin{array}{c}11.9246(16), 16.134(2), \\
7.4573(9), 125.815(2)\end{array}$ \\
\hline Unit-cell volume $\left(\AA^{3}\right)$ & $1163.4(3)$ \\
\hline$Z$ & 8 \\
\hline Calculated density $\left(\mathrm{g} / \mathrm{cm}^{3}\right)$ & 1.967 \\
\hline Absorption coefficient $\left(\mathrm{mm}^{-1}\right)$ & 0.722 \\
\hline Crystal size $\left(\mathrm{mm}^{3}\right)$ & $0.12 \times 0.10 \times 0.11$ \\
\hline \multicolumn{2}{|l|}{ Data collection } \\
\hline$\theta$ range & $2.46-36.50^{\circ}$ \\
\hline$h, k, /$ ranges & $-17 \rightarrow 19,-26 \rightarrow 26,-10 \rightarrow 12$ \\
\hline Total reflections collected & 9817 \\
\hline Unique reflections $\left(R_{\text {int }}\right)$ & $2831(0.052)$ \\
\hline Unique reflections $F>4 \sigma(F)$ & 2034 \\
\hline \multicolumn{2}{|l|}{ Structure refinement } \\
\hline Refinement method & Full-matrix least-squares on $F^{2}$ \\
\hline Weighting coefficients $a, b$ & $0.0579,0$ \\
\hline Data/restraints/parameters & $2831 / 0 / 111$ \\
\hline$R_{1}[F>4 \sigma(F)], w R_{2}[F>4 \sigma(F)]$ & $0.044,0.097$ \\
\hline$R_{1}, w R_{2}$ [all data] & $0.072,0.111$ \\
\hline Goodness-of-fit on $F^{2}$ & 1.024 \\
\hline $\begin{array}{l}\text { Largest diff. peak and hole, } \\
e \AA^{-3}\end{array}$ & $0.875,-0.574$ \\
\hline
\end{tabular}

(above $3500 \mathrm{~cm}^{-1}$ ), substantial deviations from this correlation are possible because the $\mathrm{O}-\mathrm{H}$ stretching frequencies depend not only on the $\mathrm{O} \cdots \mathrm{O}$ distances, but also on the nature of cations coordinating $\mathrm{O}-\mathrm{H}$ groups and $\mathrm{H}_{2} \mathrm{O}$ molecules, as well as on the $\mathrm{O}-\mathrm{H} \cdots \mathrm{O}$ bond angle. The influence of these factors becomes most pronounced for weak hydrogen bonds. The above correlation predicts that the maximum possible value of the $\mathrm{O}-\mathrm{H}$ stretching frequency for minerals is 3592 $\mathrm{cm}^{-1}$. However, in IR spectra of many minerals bands of $\mathrm{O}-\mathrm{H}$ stretching vibrations with higher $v$ values are present. For example, in the IR spectra of the magnesium serpentine-group minerals brucite and kaolinite, strong absorption bands with frequencies even higher than $3660 \mathrm{~cm}^{-1}$ can be observed.

The frequencies of the $\mathrm{O}-\mathrm{H}$ stretching vibrations for hydrogen bonds with $\mathrm{O}$ as an acceptor, measured from the IR spectrum and calculated from the Libowitzky equation and corresponding $\mathrm{d}(\mathrm{O} \cdots \mathrm{O})$ distances $(\AA)$ are $\left[v_{\text {meas }} / v_{\text {calc }} / \mathrm{d}(\mathrm{O} \cdots \mathrm{O})\right]: 3421 / 3476 / 2.986$, 3293/3234/2.716, 3190/3215/2.709, 3164/3195/2.699, 2989/2919/2.632. Consequently, the IR bands at 3490,3585 , and $3640 \mathrm{~cm}^{-1}$ can be assigned to weaker hydrogen bonds with $\mathrm{Cl}$ as an acceptor, with the distances $\mathrm{O} \cdots \mathrm{Cl}$ equal to $3.055,3.128$, and $3.241 \AA$, respectively.
In accordance with the Libowitzky equation, the strongest hydrogen bond corresponds to the shortest $\mathrm{O} \cdots \mathrm{O}$ distance of $2.632 \AA$ between $\mathrm{O}_{\mathrm{w}} 2$ and $\mathrm{O} 7$ and to the lowest frequency of $\mathrm{O}-\mathrm{H}$ stretching vibrations of $2989 \mathrm{~cm}^{-1}$. Note that the $\mathrm{O} 7$ atom has the largest displacement parameters, which provides a possible explanation for the occurrence of weak IR bands (at 2299,2445 , and $2521 \mathrm{~cm}^{-1}$ ) that can be assigned to small amounts of protonated $\mathrm{HSO}_{4}^{-}$groups.

\section{ACKNOWLEDGEMENTS}

This work was financially supported by the Russian Foundation for Basic Research (grants nos. 11-05-00397-a, 11-05-00407-a). SVK and APC were supported in this work by the Russian Federal Grant-inAid Program 'Cadres' (state contract 16.740.11.0490). $\mathrm{X}$-ray diffraction studies were performed at the SPbSU $\mathrm{X}$-ray diffraction Resource Centre. The authors are grateful to P.C. Piilonen, J. Schlüter, H. Friis, and L.A. Groat for valuable comments.

\section{REFERENCES}

Brese, N. \& O'KeefFe, M. (1991) Bond-valence parameters for solids. Acta Crystallographica B47, 192-197.

Chukanov, N.V., Mukhanova, A.A., Möckel, S., BelaKOVSKIY, D.I., \& LEVITSKAYA, L.A. (2010) Nickeltalmessite, $\mathrm{Ca}_{2} \mathrm{Ni}\left(\mathrm{AsO}_{4}\right)_{2} \cdot 2 \mathrm{H}_{2} \mathrm{O}$, a new mineral species of the fairfieldite group, Bou Azzer, Morocco. Geology of Ore Deposits 52, 606-611.

Chukanov, N.V., Pekov, I.V., Jonsson, E., Zubkova, N.V., Filinchuk, Y.E., Belakovsliy, D.I., \& Pushcharovsky D.YU. (2011) Långbanshyttanite, a new arsenate mineral from Långban, Sweden. European Journal of Mineralogy 23, 675-681.

Chukanov, N.V., Scholz, R., Aksenov, S.M., Rastsvetaeva, R.K., Pekov, I.V., Belakovskiy, D.I., KramBrock, K., Paniago, R.M., Righi, A., Martins, R.F., Belotti, F.M., \& Bermanec, V. (2012) Metavivianite, $\mathrm{Fe}^{2+} \mathrm{Fe}^{3+}{ }_{2}\left(\mathrm{PO}_{4}\right)_{2}(\mathrm{OH})_{2} \cdot 6 \mathrm{H}_{2} \mathrm{O}$ : new data and formula revision. Mineralogical Magazine 76, 725-741.

EuRopean STANDARD EN 883 (2005) Chemicals used for treatment of water intended for human consumption Polyaluminium chloride hydroxyde and polyaluminium chloride hydroxyde sulfate. Brussels: European Committee of Standartization. $18 \mathrm{p}$.

Hawthorne, F.C., Krivovichev, S.V., \& Burns, P.C. (2000) Crystal chemistry of sulfate minerals. Reviews in Mineralogy and Geochemistry 40, 1-112.

KIRILENKO, I.A. (2010) Glass formation in the $\mathrm{Al}_{2}\left(\mathrm{SO}_{4}\right)_{3}-$ $\mathrm{AlCl}_{3}-\mathrm{H}_{2} \mathrm{O}$ system. Russian Journal of Inorganic Chemistry 55(7), 1133-1135. 
TABLE 4. COORDINATES, DISPLACEMENT PARAMETERS $\left(\AA^{2}\right)$, AND BOND-VALENCE SUMS (BVS, V.U.) OF ATOMS IN THE STRUCTURE OF VENDIDAITE

\begin{tabular}{|c|c|c|c|c|c|c|}
\hline Atom & $\mathrm{BVS}^{*}$ & $x$ & $y$ & $z$ & $U_{\text {iso }}$ & \\
\hline$S$ & 5.94 & 0 & $0.10237(3)$ & $1 / 4$ & $0.01429(11)$ & \\
\hline $\mathrm{Al}$ & 3.08 & $0.31915(4)$ & $-0.17116(3)$ & $0.60126(7)$ & $0.01191(11)$ & \\
\hline $\mathrm{Cl}$ & - & $1 / 2$ & $0.06935(3)$ & $3 / 4$ & $0.02098(13)$ & \\
\hline $\mathrm{O}_{\mathrm{h}} 1$ & 1.14 & $0.35676(12)$ & $-0.27909(7)$ & $0.5655(2)$ & $0.0148(2)$ & \\
\hline $\mathrm{O}_{\mathrm{w}} 2$ & 0.50 & $0.24890(13)$ & $-0.06937(7)$ & $0.6279(2)$ & $0.0175(2)$ & \\
\hline $\mathrm{O}_{\mathrm{w}} 3$ & 0.45 & $0.34579(14)$ & $-0.19724(8)$ & $0.8792(2)$ & $0.0208(2)$ & \\
\hline $\mathrm{O}_{\mathrm{h}} 4$ & 1.12 & $1 / 2$ & $-0.13153(10)$ & )$^{3 / 4}$ & $0.0156(3)$ & \\
\hline O5 & 1.47 & $0.03589(13)$ & $0.15476(8)$ & $0.4400(2)$ & $0.0234(3)$ & \\
\hline $\mathrm{O}_{w} 6$ & 0.47 & $0.28253(14)$ & $-0.12493(8)$ & $0.3328(2)$ & $0.0202(2)$ & \\
\hline 07 & 1.50 & $0.11995(14)$ & $0.05040(8)$ & $0.3153(2)$ & $0.0258(3)$ & \\
\hline $\mathrm{H} 1$ & - & $0.208(3)$ & $-0.0315(19)$ & $0.517(5)$ & $0.055(9)$ & \\
\hline $\mathrm{H} 2$ & - & $0.388(3)$ & $-0.2496(16)$ & $0.948(5)$ & $0.044(8)$ & \\
\hline $\mathrm{H} 3$ & - & $1 / 2$ & $-0.084(2)$ & $3 / 4$ & $0.028(9)$ & \\
\hline $\mathrm{H} 4$ & - & $0.393(3)$ & $-0.1671(19)$ & $0.970(5)$ & $0.054(9)$ & \\
\hline H5 & - & $0.201(3)$ & $-0.1262(16)$ & $0.206(4)$ & $0.045(8)$ & \\
\hline $\mathrm{H} 6$ & - & $0.349(3)$ & $-0.110(2)$ & $0.321(5)$ & $0.071(11)$ & \\
\hline $\mathrm{H} 7$ & - & $0.414(3)$ & $-0.2935(19)$ & $0.573(5)$ & $0.058(10)$ & \\
\hline $\mathrm{H} 8$ & - & $0.207(3)$ & $-0.069(2)$ & $0.684(5)$ & $0.065(10)$ & \\
\hline Atom & $U_{11}$ & $U_{22}$ & $U_{33}$ & $U_{23}$ & $U_{13}$ & $U_{12}$ \\
\hline$S$ & $0.0134(2)$ & $0.0174(2)$ & $0.0127(2)$ & 0 & $0.00799(19)$ & 0 \\
\hline $\mathrm{Al}$ & $0.0101(2)$ & $0.01417(19)$ & $0.0116(2)$ & $-0.00004(15)$ & $0.00643(17)$ & $-0.00024(14)$ \\
\hline $\mathrm{Cl}$ & $0.0224(3)$ & $0.0212(2)$ & $0.0231(3)$ & 0 & $0.0154(2)$ & 0 \\
\hline $\mathrm{O}_{\mathrm{h}} 1$ & $0.0108(5)$ & $0.0166(5)$ & $0.0176(5)$ & $-0.0012(4)$ & $0.0086(4)$ & $0.0004(4)$ \\
\hline $\mathrm{O}_{\mathrm{w}} 2$ & $0.0201(6)$ & $0.0173(5)$ & $0.0201(5)$ & $0.0028(4)$ & $0.0145(5)$ & $0.0039(4)$ \\
\hline $\mathrm{O}_{\mathrm{w}} 3$ & $0.0266(7)$ & $0.0194(5)$ & $0.0154(5)$ & $0.0004(4)$ & $0.0117(5)$ & $-0.0007(5)$ \\
\hline $\mathrm{O}_{\mathrm{h}} 4$ & $0.0122(7)$ & $0.0138(6)$ & $0.0185(7)$ & 0 & $0.0077(6)$ & 0 \\
\hline $\mathrm{O} 5$ & $0.0224(6)$ & $0.0274(6)$ & $0.0178(5)$ & $-0.0082(5)$ & $0.0104(5)$ & $-0.0039(5)$ \\
\hline $\mathrm{O}_{\mathrm{w}} 6$ & $0.0159(5)$ & $0.0314(6)$ & $0.0132(5)$ & $0.0031(4)$ & $0.0084(4)$ & $-0.0028(5)$ \\
\hline $\mathrm{O} 7$ & $0.0262(7)$ & $0.0313(6)$ & $0.0291(7)$ & $0.0138(5)$ & $0.0213(6)$ & $0.0133(5)$ \\
\hline
\end{tabular}

* calculated using bond-valence parameters taken from Brese \& O'Keeffe (1991); contribution from $\mathrm{H}$ bonds are not included.

TABLE 5. SELECTED INTERATOMIC DISTANCES (Å) AND GEOMETRY OF HYDROGEN BONDING IN THE STRUCTURE OF VENDIDAITE

\begin{tabular}{|c|c|c|c|c|c|}
\hline S-O7 & $1.4737(13) \times 2$ & $\mathrm{Al}-\mathrm{O}_{\mathrm{h}} 1$ & $1.8559(12)$ & & \\
\hline S-O5 & $1.4820(13) \times 2$ & $\mathrm{Al}-\mathrm{O}_{\mathrm{h}} 4$ & $1.8682(7)$ & & \\
\hline \multirow[t]{2}{*}{$<\mathrm{S}-\mathrm{O}\rangle$} & 1.478 & $\mathrm{Al}-\mathrm{O}_{\mathrm{h}} 1$ & $1.8810(12)$ & & \\
\hline & & $\mathrm{Al}-\mathrm{O}_{\mathrm{w}} 2$ & $1.9061(13)$ & & \\
\hline $\mathrm{Cl}-\mathrm{O}_{\mathrm{w}} 3$ & $3.0552(14) \times 2$ & $\mathrm{Al}-\mathrm{O}_{\mathrm{w}} 6$ & $1.9315(13)$ & & \\
\hline \multirow[t]{2}{*}{$\mathrm{Cl}-\mathrm{O}_{\mathrm{w}} 6$} & $3.1282(14) \times 2$ & $\mathrm{Al}-\mathrm{O}_{\mathrm{w}} 3$ & $1.9502(14)$ & & \\
\hline & & $<\mathrm{Al}-\mathrm{O}>$ & 1.899 & & \\
\hline D-H & $\mathrm{d}(\mathbf{D}-\mathrm{H})$ & $d(H \cdots A)$ & $<$ DHA & $\mathrm{d}(\mathbf{D} \cdots \mathbf{A})$ & A \\
\hline $\mathrm{O}_{\mathrm{h}} 1-\mathrm{H} 7$ & 0.690 & 2.343 & 155.72 & 2.986 & O5 \\
\hline $\mathrm{O}_{\mathrm{w}} 2-\mathrm{H} 1$ & 0.909 & 1.804 & 173.06 & 2.709 & $\mathrm{O} 7$ \\
\hline $\mathrm{O}_{\mathrm{w}} 2-\mathrm{H} 8$ & 0.816 & 1.823 & 171.07 & 2.632 & $\mathrm{O} 7$ \\
\hline $\mathrm{O}_{\mathrm{w}} 3-\mathrm{H} 2$ & 0.963 & 1.737 & 176.59 & 2.699 & $\mathrm{O5}$ \\
\hline $\mathrm{O}_{\mathrm{w}} 3-\mathrm{H} 4$ & 0.752 & 2.315 & 168.38 & 3.055 & $\mathrm{Cl}$ \\
\hline $\mathrm{O}_{\mathrm{h}} 4-\mathrm{H} 3$ & 0.767 & 2.474 & 180.00 & 3.241 & $\mathrm{Cl}$ \\
\hline $\mathrm{O}_{\mathrm{w}} 6-\mathrm{H} 5$ & 0.876 & 1.856 & 166.85 & 2.716 & O5 \\
\hline $\mathrm{O}_{\mathrm{w}} 6-\mathrm{H} 6$ & 0.881 & 2.251 & 173.63 & 3.128 & $\mathrm{Cl}$ \\
\hline
\end{tabular}

$\mathbf{D}=$ donor $; \mathbf{A}=$ acceptor 
LiBowitZKy, E. (1999) Correlation of O-H stretching frequencies and $\mathrm{O}-\mathrm{H} \cdots \mathrm{O}$ hydrogen bond lengths in minerals. Monatshefte für Chemie 130, 1047-1059.

MalchereK, T. \& SchlÜter, J. (2010) Anatacamite from La Vendida mine, Sierra Gorda, Atacama desert, Chile: a triclinic polymorph of $\mathrm{Cu}_{2}(\mathrm{OH})_{3} \mathrm{Cl}$. Neues Jahrbuch für Mineralogie, Monatshefte, 187(3), 307-312.

Nestola, F., Cámara, F., Chukanov, N.V., Atencio, D., Coutinho, J.M.V., Contreira Filho, R.R., \& FÄrber, G. (2012) Witzkeite: a new rare nitrate-sulphate mineral from a guano deposit at Punta de Lobos, Chile. American Mineralogist 97, 1783-1787.
Reich, M., Palacios, C., Parada, M.A., Fehn, U., Cameron, E.M., Leybourne, M.I., \& ZúñIgA, A. (2008) Atacamite formation by deep saline waters in copper deposits from the Atacama Desert, Chile: evidence from fluid inclusions, groundwater geochemistry, TEM, and ${ }^{36} \mathrm{Cl}$ data. Mineralium Deposita 43, 67-73.

SchlÜter, J., Klaska, K.H., \& Gebhard, G. (2000) Belloite, $\mathrm{Cu}(\mathrm{OH}) \mathrm{Cl}$, a new mineral from Sierra Gorda, Antofagasta, Chile. Neues Jahrbuch für Mineralogie, Monatshefte 2, 67-73.

Received April 28, revised manuscript accepted september 19, 2013. 